\title{
Determining The Pressure Combination During Mechanical Ventilation that is Best Compatible with the Rapid Shallow Breathing Index Calculated in Spontaneous Ventilation
}

\author{
Şenay Yılmaz², Müge Aydoğdu², Gül Gürsel² \\ ${ }^{1}$ Department of Pulmonary Diseases, Eskişehir Osmangazi University School of Medicine, Eskişehir, Turkey \\ ${ }^{2}$ Department of Pulmonary Critical Care Medicine, Gazi University School of Medicine, Ankara, Turkey
}

\begin{abstract}
Objective: The rapid shallow breathing index (RSBI) is relatively the best predictive parameter for initial assessment of readiness for the discontinuation of mechanical ventilation (MV) support. In this study, we aimed to determine the best pressure combinations that can predict successful RSBI closest to the values calculated in spontaneous ventilation (SV).

Methods: Twenty-five mechanically ventilated patients were enrolled in the study. RSBI and other weaning parameters were calculated in

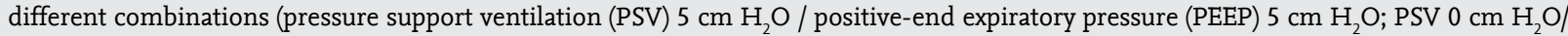

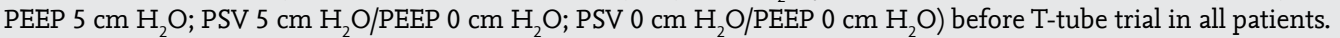

Results: The mean age of the patients was $73 \pm 10$ years. RSBI did not differ significantly between $\mathrm{SV}$ and other combinations. The best correlation with SV was found with $5 \mathrm{~cm} \mathrm{H}_{2} \mathrm{O}$ PSV- $0 \mathrm{~cm} \mathrm{H}_{2} \mathrm{O} P E E P(\mathrm{p}=0.0001, \mathrm{r}=0.719)$ and the worst with $0 \mathrm{~cm} \mathrm{H}_{2} \mathrm{O}$ PSV-5 cm H $\mathrm{H}_{2} \mathrm{O}$ PEEP. RSBI showed no predictive value for weaning success. Respiration rate $(\mathrm{f})$ was higher in failure than in the success group in PSV $0 \mathrm{~cm} \mathrm{H}_{2} \mathrm{O} / \mathrm{PEEP}$ $5 \mathrm{~cm} \mathrm{H}_{2} \mathrm{O}$ and PSV $5 \mathrm{~cm} \mathrm{H}_{2} \mathrm{O} / \mathrm{PEEP} 0 \mathrm{~cm} \mathrm{H}_{2} \mathrm{O}(\mathrm{p}=0.030, \mathrm{p}=0.030$, respectively). $\mathrm{f} \leq 27$ was considered as a predictive factor for spontaneous breathing trial (SBT) success (PSV $0 \mathrm{~cm} \mathrm{H}_{2} \mathrm{O} / \mathrm{PEEP} 5 \mathrm{~cm} \mathrm{H}_{2} \mathrm{O}$; sensitivity 93\%, specificity 63\%, PSV $15 \mathrm{~cm} \mathrm{H}_{2} \mathrm{O}$-PEEP $5 \mathrm{~cm} \mathrm{H}_{2} \mathrm{O}$; sensitivity $81 \%$, specificity $75 \%)$.
\end{abstract}

Conclusion: There was a good correlation between RSBI measured by T-tube and different pressure combinations.

Keywords: Rapid shallow breathing index, mechanical ventilation, weaning

Received Date: 29.01.2016 Accepted Date: 17.05.2016 Available Online Date: 05.09.2016

DOI: $10.5152 /$ ejp.2016.80299

Correponding Author Şenay Yilmaz

E-mail: senaydemirtas@mynet.com

-Available online at www.eurasianjpulmonol.com .0 International License.

\section{INTRODUCTION}

Weaning is the process of decreasing ventilator support and allowing patients to assume a greater proportion of their spontaneous ventilation with the gradual reduction of ventilator support (1). In order to predict the patients' success in maintaining their spontaneous breathing and oxygenation, some parameters have been researched. Among these, the rapid shallow breathing index (RSBI) is the most studied and most accepted system with the highest predictive value $(2,3)$.

Rapid shallow breathing index, the ratio of respiratory rate to tidal volume (f/VT), was first described by Yang and Tobin in 1990, as a parameter for weaning and extubation. A RSBI greater than 105 means that the patient is not ready for weaning off the ventilator (4). Moreover, a RSBI of less than 100-105 has yielded a sensitivity of $97 \%$ and a specificity of $65 \%$ for predicting weaning success (3). The evaluation of RSBI is valuable during T-tube ventilation; and in clinical practice it is not always possible to perform this assessment.

In the present study, we aimed to estimate the patients' readiness toward weaning and to determine the pressure combination that is best compatible with the RSBI calculated by the original method, in which the measurement was done during no ventilator support. 


\section{METHODS}

\section{Patient Population}

In this self-controlled and prospective study, the patients mechanically ventilated in an intensive care unit (ICU) were included in the study. The diagnosis of the patients and the underlying etiologies of their mechanical ventilation (MV) need were recorded. Ventilators were calibrated prior to intubation and then appropriate mechanical ventilator settings were done according to each patient's need. All the patients' age, gender, comorbid diseases, smoking history, diagnosis of intubation, intubation and extubation days, weaning trial day, weaning success, length of hospitalization, length of MV and ICU stay, need for re-intubation, outcome (exitus or discharge to home/ ward), and causes of mortality were recorded.

\section{Weaning Protocol}

In the first 24 hours, patients were ventilated by assist-controlled ventilation mode (ACV) with varying fractions of inspired oxygen $\left(\mathrm{FIO}_{2}\right)$ values providing oxygen saturation measured by pulse oximeter $\left(\mathrm{SpO}_{2}\right)>90 \%$. Beginning from the second day, daily screening (DS) was done according to the following criteria (5-7): the cause of intubation has improved; $\mathrm{Pa} \mathrm{O}_{2} / \mathrm{FIO}_{2}>200$ (if $\mathrm{FIO}_{2}$ of $40-50 \%, \mathrm{PaO}_{2}$ $>60 \mathrm{mmHg}$ ), positive-end expiratory pressure (PEEP) $\leq 5 \mathrm{~cm} \mathrm{H}_{2} \mathrm{O}$, f/VT $<105$ breaths/min/L, $\mathrm{f}<35 / \mathrm{min}$, sufficient cough reflex during aspirations, no need for a vasopressor or sedative agent (intermittent sedative or dopamine below $5 \mathrm{\mu g} / \mathrm{kg} / \mathrm{min}$ is acceptable), and no fever.

Spontaneous breathing trial (SBT) was applied to patients who met the DS criteria. The T-tube method was applied for the SBT circuit for up to 30 minutes. While measuring different combinations, the mean of multiple values at some period of the SBT was recorded. SBT was finished in case of the following events (8): $f>35 / \mathrm{min}, \mathrm{SaO}_{2}<90 \%$, heart rate $>140$ min or an increase or decrease of $20 \%$ in heart rate, systolic blood pressure $>200 \mathrm{mmHg}$ or $<80 \mathrm{mmHg}$, development of agitation, diaphoresis, anxiety, etc.

Pressure support ventilation (PSV) of $15 \mathrm{cmH}_{2} \mathrm{O} / \mathrm{PEEP} 5 \mathrm{~cm} \mathrm{H}_{2} \mathrm{O}$ with $\mathrm{FIO}_{2} \leq 40 \%$ was determined as the starting setting. The PSV settings were decreased as soon as possible. Prior to disconnection, measurements were done in different PSV and PEEP combinations with $\mathrm{FIO}_{2}$ $\leq 40 \%$.

\section{Preparing the Patients for the Study}

The ethics committee of Gazi University approved the study. Also, the procedures performed in this study were in accordance with the Helsinki Declaration. Informed consent was obtained either from patients (if competent) or their family.

The ventilator settings were controlled initially and saved; the patient was put in to a semi-sitting position and then an endotracheal tube was aspirated. The latest measurements of the blood gas values and the patient's vital signs were recorded in PSV start-up mode. The filter available in the patient's intubation tube was removed at least 2 minutes before the measurements. Then, the measurements were recorded at different PSV and PEEP values with $\mathrm{FIO}_{2} \leq 40 \%$, starting from 15 $\mathrm{cm} \mathrm{H}_{2} \mathrm{O} P S V / 5 \mathrm{~cm} \mathrm{H}_{2} \mathrm{O}$ PEEP and then in the following combinations:

Combination 1: $5 \mathrm{~cm} \mathrm{H}_{2} \mathrm{O}$ PSV/5 $\mathrm{cm} \mathrm{H}_{2} \mathrm{O}$ PEEP; Combination 2: $0 \mathrm{~cm}$ $\mathrm{H}_{2} \mathrm{O}$ PSV/5 cm H $\mathrm{H}_{2} \mathrm{O}$ PEEP; Combination 3: $5 \mathrm{~cm} \mathrm{H}_{2} \mathrm{O}$ PSV/O $\mathrm{cm} \mathrm{H}_{2} \mathrm{O}$
PEEP; Combination 4: $0 \mathrm{~cm} \mathrm{H}_{2} \mathrm{O}$ PSV/O $\mathrm{cm} \mathrm{H}_{2} \mathrm{O}$ PEEP, Combination 5: spontaneous ventilation.

These combinations were applied randomly for each patient. The patients were allowed to rest for 15 minutes in the PSV $15 \mathrm{~cm} \mathrm{H}_{2} \mathrm{O} / \mathrm{PEEP}$ $5 \mathrm{~cm} \mathrm{H}_{2} \mathrm{O}$ with $\mathrm{FIO}_{2}$ of $40 \%$ mode during the intervals of each combination. The measurements were done with a respiratory monitor for volumetric capnography (COSMO PLUS, Novometrix). After calibrating the device, the values of the alveolar ventilation (VE), respiratory rate (f), tidal volume (VT), $\mathrm{RSBI}, \mathrm{SaO}_{2^{\prime}}$ and $\mathrm{PaCO}_{2}$ were recorded on the related forms and tables.

The patients who passed SBT successfully were extubated and followed by close monitoring in the first 24-48 hours of extubation. When weaning failure occurred, the combination of PSV and PEEP in which the weaning failure was noticed, the causes of this weaning failure, arterial blood gas values, and the vitals findings were recorded. Noninvasive mechanical ventilation (NIMV) was applied to appropriate patients suffering from respiratory failure in the post-extubation period; otherwise they were intubated again and the causes of extubation failure were recorded. Finally, the patient's length of ICU stay, length of MV and hospital stay, the initial day of the weaning trial, the number of weaning trials, and the day and causes of mortality were all recorded.

\section{Criteria for Exclusion from the Study}

The patients who did not meet the DS criteria, those who met the DS criteria but could not tolerate SBT, and those who refused to join the study were excluded from the study.

\section{Statistical Analysis}

All the data recorded in the study were analyzed by using the Statistical Package for the Social Sciences Windows 10.0 (SPSS Inc.; Chicago, IL, USA) program. The results are quoted as the average \pm standard deviation. The $t$ test and Mann-Whitney $U$ test were applied for the comparisons between groups. The paired t-test method was used for the binary comparison of modes. We aimed to compare the values measured in each combination with the values measured in spontaneous breathing calculated standard methods in the literature. Correlations between all the numerical parameters and modes were examined. The results of the Kolmogorov-Smirnov test, which was used to examine the data, showed a non-normal distribution. The values of the sensitivity and specificity were also calculated so the Mann-Whitney $U$ test was used primarily for the variables with a non-normal distribution. We could not give the outcome of the mean values with the Mann-Whitney $U$ test so the $t$ test was used for the mean values with normal distribution. Significant values were the same in the two tests. Correlation was analyzed by the Spearman rank correlation coefficient. A statistical $p$ value below 0.05 was accepted as statistically significant.

\section{RESULTS}

Twenty-five patients, 11 of whom were male and whose mean age was $73 \pm 10$ years, were included in the study. They were intubated in the ICU. The demographic features of the patients are given in Table 1.

During intubation, tube number 8 was used for 23 patients and tube number 7.5 for 2 patients. Sixty-eight percent of the patients were ventilated for $\geq 7$ days. The possible causes of longer ventilation were 
Table 1. Demographic features and admission diagnosis of the patients

\begin{tabular}{|c|c|}
\hline Variables & $\begin{array}{c}n=25 \\
\text { Mean } \pm S D\end{array}$ \\
\hline Age (years) & $73 \pm 10$ \\
\hline Sex (Female) n(\%) & $11(44)$ \\
\hline Smoking, n (\%) & $14(56)$ \\
\hline \multicolumn{2}{|l|}{ Admission diagnosis, $\mathrm{n}(\%)$} \\
\hline COPD & $13(52)$ \\
\hline $\begin{array}{l}\text { Restrictive lung diseases (kyphoscoliosis, } \\
\text { obstructive sleep apnea syndrome) }\end{array}$ & $5(20)$ \\
\hline Pneumonia & $5(20)$ \\
\hline Pulmonary thromboembolism & $2(8)$ \\
\hline $\begin{array}{l}\text { Cardiac dysfunction (congestive heart failure, } \\
\text { hypertensive attack) }\end{array}$ & $3(12)$ \\
\hline Acute renal failure & $1(4)$ \\
\hline APACHE II score & $19 \pm 6$ \\
\hline Home long term oxygen therapy use $n(\%)$ & $5(20)$ \\
\hline
\end{tabular}

Table 2. Weaning parameters measured in different pressure combinations

\begin{tabular}{|c|c|c|c|c|}
\hline Modes & $\begin{array}{c}\mathrm{VT}(\mathrm{mL}) \\
\text { Mean } \pm \text { SD }\end{array}$ & $\begin{array}{l}\text { VE }(\mathrm{L} / \mathrm{min}) \\
\text { Mean } \pm \mathrm{SD}\end{array}$ & $\begin{array}{c}f(/ \min ) \\
\text { Mean } \pm S D\end{array}$ & $\begin{array}{l}\text { RSBI (f/VT) } \\
\text { Mean } \pm \text { SD }\end{array}$ \\
\hline PSV15 PEEP5 & $508 \pm 188$ & $10 \pm 3$ & $21 \pm 8$ & Not measured \\
\hline PSV5 PEEP5 & $369 \pm 187$ & $9 \pm 5$ & $31 \pm 8$ & $120 \pm 64$ \\
\hline PSV0 PEEP5 & $308 \pm 142$ & $8 \pm 4$ & $32 \pm 10$ & $153 \pm 73$ \\
\hline PSV5 PEEP0 & $313 \pm 127$ & $9 \pm 3$ & $30 \pm 7$ & $117 \pm 60$ \\
\hline PSVO PEEPO & $312 \pm 167$ & $8 \pm 3$ & $30 \pm 9$ & $131 \pm 83$ \\
\hline Spontaneous & $295 \pm 129$ & $9 \pm 4$ & $28 \pm 8$ & $115 \pm 70$ \\
\hline \multicolumn{5}{|c|}{$\begin{array}{l}\text { f: Respiration rate; PSV: pressure support ventilation; PEEP: positive-end } \\
\text { expiratory pressure; RSBI: rapid shallow breathing index; VE: alveolar } \\
\text { ventilation;VT: tidal volume }\end{array}$} \\
\hline
\end{tabular}

identified as sepsis, agitation, renal failure, ischemic heart disease, and metabolic acidosis. While the patients stayed in hospital for an average of $29 \pm 15$ days, they were only mechanically ventilated for an average of $16 \pm 16$ days. While 11 of the 25 patients (44\%) in the study were reintubated, tracheostomy was performed in only four of them (16\%).

Different pressure combinations were randomly chosen for each patient. Fifteen $\mathrm{cm} \mathrm{H}_{2} \mathrm{O}$ PSV/5 $\mathrm{cm} \mathrm{H}_{2} \mathrm{O}$ PEEP with $\mathrm{FIO}_{2} \leq 40 \%$ was determined as the starting mode. RSBI was measured while the patient was spontaneously breathing and it was compared to the RSBI measured in other pressure combinations. The RSBI values and other weaning parameters calculated in different pressure combinations are given in Table 2. This table shows our measurements in terms of averaged numbers.
Table 3. Comparison of the demographic characteristics, arterial blood gas analysis values before weaning, and RSBI between Group A and Group B

\begin{tabular}{|c|c|c|c|}
\hline & $\begin{array}{c}\text { Group A } \\
(n=8) \\
\text { Mean } \pm \text { SD }\end{array}$ & $\begin{array}{c}\text { Group B } \\
(n=17) \\
\text { Mean } \pm \text { SD }\end{array}$ & $p$ \\
\hline Age (years) & $74 \pm 9$ & $73 \pm 11$ & 0.890 \\
\hline Sex (Female), n (\%) & $5(63)$ & $6(35)$ & 0.633 \\
\hline APACHE II score & $19 \pm 7$ & $19 \pm 6$ & 0.947 \\
\hline $\begin{array}{l}\text { Home long term oxygen therapy } \\
\text { use } \mathrm{n}(\%)\end{array}$ & $2(25)$ & $3(18)$ & 1.000 \\
\hline \multicolumn{4}{|l|}{$\begin{array}{l}\text { Arterial blood gas analysis before } \\
\text { weaning }\end{array}$} \\
\hline $\mathrm{pH}$ & $7.42 \pm 4.92$ & $7.42 \pm 6.90$ & 0.842 \\
\hline $\mathrm{PaO}_{2}(\mathrm{mmHg})$ & $83 \pm 13$ & $77 \pm 12$ & 0.260 \\
\hline $\mathrm{PaCO}_{2}(\mathrm{mmHg})$ & $41 \pm 8$ & $39 \pm 10$ & 0.633 \\
\hline $\mathrm{SaO}_{2}(\%)$ & $96 \pm 2$ & $96 \pm 3$ & 0.721 \\
\hline \multicolumn{4}{|l|}{$\mathrm{RSBI}(\mathrm{f} / \mathrm{VT})$} \\
\hline $\mathrm{RSBI}_{\text {PSV5 PEEP5 }}$ & $111 \pm 68$ & $125 \pm 63$ & 0.645 \\
\hline RSBI PSVO PEEP5 & $132 \pm 78$ & $163 \pm 71$ & 0.341 \\
\hline $\mathrm{RSBI}_{\text {PSV5 PEEP0 }}$ & $106 \pm 81$ & $122 \pm 51$ & 0.567 \\
\hline $\mathrm{RSBI}_{\text {PSVO PEEPO }}$ & $126 \pm 101$ & $133 \pm 76$ & 0.844 \\
\hline $\mathrm{RSBI}_{\text {Spontaneous }}$ & $125 \pm 92$ & $111 \pm 60$ & 0.651 \\
\hline
\end{tabular}

APACHE II: Acute physiology and chronic health evaluation II; PSV: pressure support ventilation; PEEP: positive-end expiratory pressure; RSBI: rapid shallow breathing index

$\mathrm{RSBI}$ values measured in different pressure combinations were compared to RSBI measured in spontaneous respiration and their correlations were examined. The $5 \mathrm{~cm} \mathrm{H}_{2} \mathrm{O}$ PSV/O $\mathrm{cm} \mathrm{H}_{2} \mathrm{O}$ PEEP combination had the best correlation with spontaneous respiration; $0 \mathrm{~cm} \mathrm{H}_{2} \mathrm{O}$

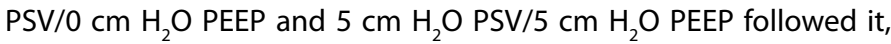
respectively, while the worst correlation was determined with $0 \mathrm{~cm}$ $\mathrm{H}_{2} \mathrm{O}$ PSV/5 $\mathrm{cm} \mathrm{H}_{2} \mathrm{O}$ PEEP (Figures 1a-d).

The patients who were extubated on the day of SBT and not reintubated within 48 hours were considered as the SBT success group and were grouped together as Group A ( $n=8)$; the patients who could not be extubated on the day of measurements or who were reintubated within 48 hours following extubation were considered as the SBT failure group and were grouped together as Group $B(n=17)$. There were no significant differences in terms of the demographic characteristics, arterial blood gas values before weaning, and RSBIs between Group A and Group B (Table 3).

Two patients (25\%) in Group A and 11 patients (65\%) in Group B had a diagnosis of chronic obstructive pulmonary disease (COPD) $(p=0.097)$. While 4 of the 8 patients (50\%) were reintubated in Group A, tracheostomy was performed in only 1 (12.5\%) patient. While 7 of the 17 patients (41.2\%) were reintubated in Group B, tracheostomy was performed in only $3(17.6 \%)$ patients. There were no statistically significant differences in terms of re-intubation and tracheostomy between the two groups $(p=1.000, p=1.000$, respectively). 


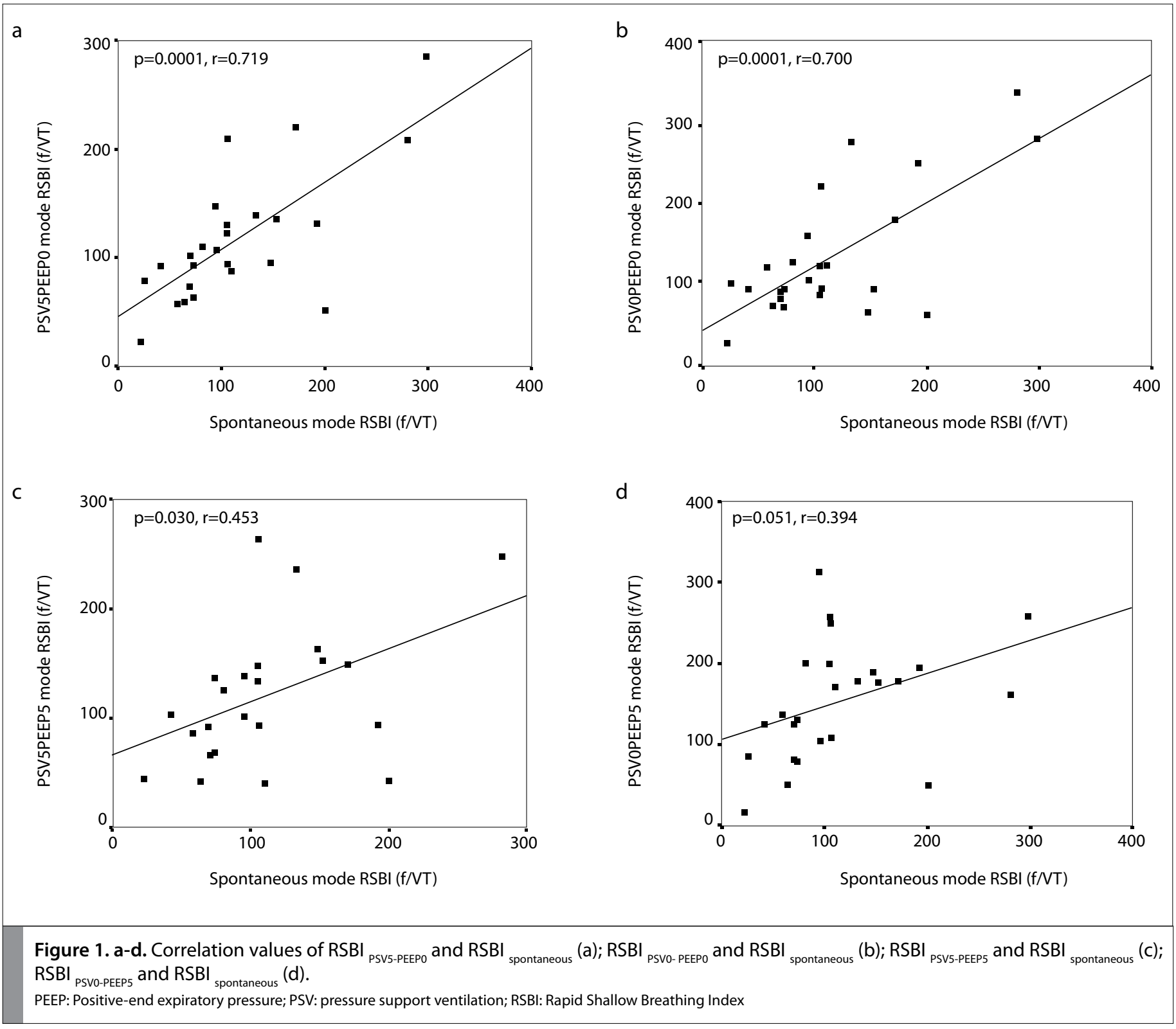

The $f$ values were significantly higher in Group B than Group A in the PSV $0 \mathrm{~cm} \mathrm{H}_{2} \mathrm{O} /$ PEEP $5 \mathrm{~cm} \mathrm{H}_{2} \mathrm{O}$ and PSV $5 \mathrm{~cm} \mathrm{H}_{2} \mathrm{O} /$ PEEP $0 \mathrm{~cm} \mathrm{H}_{2} \mathrm{O}$ combinations ( $p=0.030, p=0.030$, respectively). $f$ values $\leq 27$ for $P S V 0 \mathrm{~cm}$ $\mathrm{H}_{2} \mathrm{O} /$ PEEP $5 \mathrm{~cm} \mathrm{H}_{2} \mathrm{O}$ (sensitivity, 93\%; specificity, 63\%) and for PSV 5 $\mathrm{cm} \mathrm{H}_{2} \mathrm{O} /$ PEEP $5 \mathrm{~cm} \mathrm{H}_{2} \mathrm{O}$ (sensitivity, 81\%; specificity, 75\%) were considered as predictive for the SBT success.

\section{DISCUSSION}

Rapid shallow breathing index measurement has been the best predictor of weaning success among the studies carried out so far $(3,4$, $9,10)$. In this study, we aimed to determine the best pressure combinations that can predict successful RSBI closest to the values calculated by the original method of RSBI, as measured during no ventilator support. The best correlation of RSBI with spontaneous respiration was found with PSV $5 \mathrm{~cm} \mathrm{H}_{2} \mathrm{O} /$ PEEP $0 \mathrm{~cm} \mathrm{H}_{2} \mathrm{O}$ and the worst with PSV $0 \mathrm{~cm} \mathrm{H}_{2} \mathrm{O} /$ PEEP $5 \mathrm{~cm} \mathrm{H}_{2} \mathrm{O}$. In spite of these pressure combinations showing a good correlation with spontaneous breathing, a threshold value for RSBI could not be detected to predict the SBT success.
The time spent in the weaning process represents $40-50 \%$ of the total duration of $\operatorname{MV}(7,11)$. If weaning from MV has to be postponed due to some reasons, not only will the cost increase but also some complications could occur, such as airway trauma or ventilator-associated pneumonia (VAP) (12-14). Esteban and his colleagues stressed that the longer the length of MV, the higher the mortality rate (11). So, reliable parameters are necessary for a successful weaning time. The highest predictive value has been identified for RSBI, but for measuring RSBI in spontaneous ventilation, a patient must be removed from the ventilator, followed in t-tube, and a spirometry or capnography should then be applied. Because of the complexity of the procedure, we tried to find out whether RSBI measured in different pressure combinations during MV can reflect close measurements to $\mathrm{RSBI}_{\text {spontaneous }}$ and whether it could be used for the prediction of weaning success.

Rapid shallow breathing index is a parameter measured at the beginning of SBT (10). During the weaning process, a RSBI measured at the first minute of t-tube trial below 105 is a strong predictor of safe 
weaning and successful extubation. A sensitivity of $97 \%$ and a specificity of $65 \%$ were found for this threshold value $(3,15,16)$. However, it was found in some studies that RSBI did not have enough efficiency during its routine use for weaning, especially during prolonged MV. The most suitable RSBI value was measured as 97 in one study that evaluated the efficiencies of the weaning parameters, but the accuracy of Yang and Tobin's index (RSBI) with a threshold value of 105 was found to be only $59 \%$ in patients with prolonged MV $(9,17,18)$. Similarly in our study, there was prolonged MV for most of our patients. This might be the cause of not identifying a threshold value of RSBI for the prediction of SBT success.

In the study of Bien et al. (19), RSBI were performed for three 30-minute periods while the patients randomly received a T-piece, $100 \%$ inspiratory automatic tube compensation with $5 \mathrm{~cm} \mathrm{H}_{2} 0$ PEEP and $5 \mathrm{~cm}$ $\mathrm{H}_{2} \mathrm{O}$ PSV with $5 \mathrm{~cm} \mathrm{H}_{2} \mathrm{O}$ PEEP. They found that T-piece trial is the best choice for predicting the extubation outcome in ICU patients. In our study, RSBI was measured at the beginning of SBT and was recorded as a mean of multiple values at certain periods of the SBT; furthermore, it was calculated separately in different PSV and PEEP values before SBT. No significant differences were identified in both the whole study population and in the SBT success and failure groups. This is why a clear threshold could not be determined. When PS was reduced from PSV $20 \mathrm{~cm} \mathrm{H}_{2} \mathrm{O}$ to PSV $10 \mathrm{~cm} \mathrm{H}_{2} \mathrm{O}$, the f and $\mathrm{RSBI}$ values significantly increased while VT significantly decreased. These parameters did not vary when PSV was reduced from $\mathrm{PSV} 10 \mathrm{~cm} \mathrm{H}_{2} \mathrm{O}$ to PSV $5 \mathrm{~cm} \mathrm{H}_{2} \mathrm{O}$ (20). In a prospective study by El-Khatib et al. (21), RSBI values under various ventilator support settings prior to extubation were evaluated. Similar to our study, they compared RSBI measured as $0 \mathrm{~cm} \mathrm{H} \mathrm{H}_{2} \mathrm{OPSV} / 5 \mathrm{~cm} \mathrm{H}_{2} \mathrm{O}$ PEEP and $40 \% \mathrm{FiO}_{2}, 0 \mathrm{~cm} \mathrm{H} \mathrm{H}_{2} \mathrm{OPSV} / 5 \mathrm{~cm} \mathrm{H}_{2} \mathrm{O}$ $\mathrm{PEEP}$ and $21 \% \mathrm{FiO}_{2}$, and a 1 minute spontaneously breathing room air trial off the ventilator (T-piece). They found that in the same patient with the use of PSV and/or PEEP as low as $5 \mathrm{~cm} \mathrm{H}_{2} \mathrm{O}$, smaller RSBI values were identified when compared with the ones measured during the T-piece. They found no effects from changes in $\mathrm{FiO}_{2}$ on the RSBI values (21).

We determined the starting mode as PSV $15 \mathrm{~cm} \mathrm{H}_{2} \mathrm{O} /$ PEEP $5 \mathrm{~cm} \mathrm{H}_{2} \mathrm{O}$ with $\mathrm{FiO}_{2} \leq 40 \%$. RSBI was measured while the patient was breathing spontaneously and was compared to the RSBI values measured in other combinations. Although a PSV of $7 \mathrm{~cm} \mathrm{H}_{2} \mathrm{O}$ was used to overcome the resistance of the ventilator circuit in the literature, we chose a PSV of $5 \mathrm{~cm} \mathrm{H}_{2} \mathrm{O}$ (7). We tried multiple combinations, and found PSV $7 \mathrm{~cm} \mathrm{H}_{2} \mathrm{O}$ had a value between PSV $5 \mathrm{~cm} \mathrm{H}_{2} \mathrm{O}$ and PSV $10 \mathrm{~cm} \mathrm{H}_{2} \mathrm{O}$. The PSV $5 \mathrm{~cm} \mathrm{H}_{2} \mathrm{O} /$ PEEP $0 \mathrm{~cm} \mathrm{H}_{2} \mathrm{O}$ combination was determined as the closest measurement mode to spontaneous breathing; while PSV 0 $\mathrm{cm} \mathrm{H}_{2} \mathrm{O} /$ PEEP $0 \mathrm{~cm} \mathrm{H}_{2} \mathrm{O}$ and PSV $5 \mathrm{~cm} \mathrm{H}_{2} \mathrm{O}$ /PEEP $5 \mathrm{~cm} \mathrm{H}_{2} \mathrm{O}$ followed it, respectively, and the worst combination of correlation was determined as PSV $0 \mathrm{~cm} \mathrm{H}_{2} \mathrm{O} /$ PEEP $5 \mathrm{~cm} \mathrm{H}_{2} \mathrm{O}$. When PEEP $5 \mathrm{~cm} \mathrm{H} \mathrm{H}_{2} \mathrm{O}$ was adjusted and PSV $15 \mathrm{~cm} \mathrm{H}_{2} \mathrm{O}$ was decreased to PSV $5 \mathrm{~cm} \mathrm{H}_{2} \mathrm{O}$ and PSV $0 \mathrm{~cm} \mathrm{H}_{2} \mathrm{O}$, the RSBI and $\mathrm{f}$ values increased and VT decreased, but this was not statistically significant. When PEEP was adjusted to $0, \mathrm{RSBI}$ increased, but there was no significant change in $f$ and VT values as the PS value was decreased. This result can support VT's direct correlation with the PS level and the indirect correlation with the PS level of $f$ and $\mathrm{RSBI}$. As a result, RSBI measured on ventilator was not determined as a decisive criterion for this combination, although there were some combinations that had a good correlation with spontaneous breathing. One of the most important reasons why we could not determine a threshold value may have been the insufficient number of patients.
Similar to our study, in a study performed by Gonçalves et al. (22), the effect of low PSV on RSBI was evaluated. They measured RSBI prior to extubation while the patient was connected to the ventilator and receiving PSV and $5 \mathrm{~cm} \mathrm{H}_{2} 0$ of PEEP and then they disconnected their patients from the mechanical ventilator and then measured RSBI during spontaneous ventilation with a Wright spirometer. They found that, in patients with extubation failure, the RSBI measured in spontaneous ventilation was higher than the one measured with PSV (22).

Patel et al. (23) reported RSBI measured while the patients were on two different levels of ventilator support: $5 \mathrm{~cm} \mathrm{H}_{2} \mathrm{O}$ continuous positive airway pressure (CPAP) versus T-piece. They found that RSBI was significantly less when measured on $5 \mathrm{~cm} \mathrm{\textrm {H } _ { 2 }} 0$ CPAP compared to T-piece. In a study of Desai et al. (24), the RSBI was measured with a handheld spirometer and through the ventilator, with and without CPAP. RSBI was measured with CPAP: $0 \mathrm{~cm} \mathrm{H}_{2} \mathrm{O}$ and $40 \% \mathrm{FiO}_{2}, \mathrm{CPAP}$ : $5 \mathrm{~cm} \mathrm{H}_{2} \mathrm{O}$ and $40 \% \mathrm{FiO}_{2}$, and with the ventilator disconnected and $\mathrm{FiO}_{2}$ of $21 \%$. They found that the RSBI values measured through the ventilator with CPAP $5 \mathrm{~cm} \mathrm{H}_{2} 0$ were much lower than the values measured with a handheld spirometer. Even the RSBI values measured with CPAP $0 \mathrm{~cm} \mathrm{H}_{2} \mathrm{O}$ were significantly lower. This was attributable to the base flow delivered by some ventilators (24). Again, a recently published study by Zhang et al. (25) with quite an extensive number of patients supports our results. In their study, the authors found the diagnostic accuracy of RSBI measured during PSV with PS: $5 \mathrm{~cm} \mathrm{H}_{2} 0$ and PEEP: $5 \mathrm{~cm} \mathrm{H}_{2} \mathrm{O}$ as $87 \%$ for a threshold of 75 breaths $/ \mathrm{min} / \mathrm{L}$.

We preferred the term of "SBT success" instead of "weaning success" in our study to emphasize whether the patients were extubated or not on the day when the studies were done. We considered the patients who were extubated on the day of SBT and not reintubated within 48 hours as the "SBT success group" after a clinically objective and subjective evaluation by modifying some criteria according to the European Respiratory Journal (ERJ) definition (8). We considered the patients who could not be extubated on the day that the measurements were done or who were reintubated within 48 hours after extubation as the "SBT failure group." In the study by Sassoon et al. (26), while there were significant differences among $\mathrm{pH}, \mathrm{PaCO}_{2^{\prime}} \mathrm{PaO}_{2^{\prime}}$ and $\mathrm{FiO}_{2}$ values, there were no significant differences among VT, $\mathrm{P}_{0.1}, \mathrm{f}$, and RSBI values in the success and failure groups of weaning. Similarly in our study, there were no significant differences among RSBI, VT, $\mathrm{PaCO}_{2}$, and $\mathrm{PaO}_{2}$, values when SBT success and failure groups were compared. Some researchers have found that VT has shown a direct variability with PS and an indirect variability with $f$ and $\operatorname{RSBI}(27,28)$. The reason for this was that the patient breathed with a high VT and low $f$ when the muscles were exposed to a high PSV. Conversely, a low PSV affects RSBI. However, the studies showed that the VT and $f$ values did not decrease significantly in low PSV modes $(29,30)$. Our study also supports this, and significant differences among f, VT, RSBI, and VE values were not determined at different PSV levels.

When the other parameters used for weaning in each of the two groups were evaluated, VE was significantly different in the PSV $0 \mathrm{~cm}$ $\mathrm{H}_{2} \mathrm{O} / \mathrm{PEEP} 5 \mathrm{~cm} \mathrm{H}_{2} \mathrm{O}$ combination. There are lots of studies in the literature investigating the value of the respiratory rate in weaning success and that report different cut-off values, such as 38 breaths/min or 35 breaths/min $(2,20)$. In our study, the f values in the SBT failure group were higher than in the SBT success group and the threshold for the PSV $0 \mathrm{~cm} \mathrm{H}_{2} \mathrm{O} /$ PEEP $5 \mathrm{~cm} \mathrm{H}_{2} \mathrm{O}$ and PSV $5 \mathrm{~cm} \mathrm{H}_{2} \mathrm{O} /$ PEEP $0 \mathrm{~cm}$ $\mathrm{H}_{2} \mathrm{O}$ combinations were measured as 27 . This can be interpreted that 
the weaning success may be low in patients who have values of $\mathrm{f}>27$ with these pressure combinations. The $\mathrm{f} \leq 27$ (sensitivity, 93\%; specificity, 63\%) for PSV $0 \mathrm{~cm} \mathrm{H}_{2}$ O/PEEP $5 \mathrm{~cm} \mathrm{H}_{2} \mathrm{O}$ mode and $\mathrm{f} \leq 27$ (sensitivity, 81\%; specificity, 75\%) for PSV $5 \mathrm{~cm} \mathrm{H}_{2} \mathrm{O} /$ PEEP $0 \mathrm{~cm} \mathrm{H}_{2} \mathrm{O}$ mode were considered as a success of SBT. These results support the previous studies also and underscore the importance of $f$ during weaning evaluations.

The weakness of our study was the insufficient number of patients, so we could not determine a threshold value for RSBI. Similar to other studies, there was prolonged MV for most of our patients. This might be the cause of not identifying a threshold value of RSBI for the prediction of SBT success.

\section{CONCLUSION}

There was a good correlation between RSBI measured in T-tube and $\mathrm{RSBI}$ measured in different pressure combinations, especially the combination of "PSV $5 \mathrm{~cm} \mathrm{H}_{2} \mathrm{O} / \mathrm{PEEP} 0 \mathrm{~cm} \mathrm{H}_{2} \mathrm{O}$," during the assistance of the ventilator, and a $27 / \mathrm{min}$ threshold value for the respiration rate gave a relatively good predictive value for SBT success.

Ethics Committee Approval: Ethics committee approval was received for this study from the ethics committee of Gazi University.

Informed Consent: Written informed consent was obtained from from patients (if competent) or from their family who participated in this study.

Peer-review: Externally peer-reviewed.

Author Contributions: Concept - S.Y., G.G.; Design - S.Y.; Supervision - S.Y., G.G.; Resources - S.Y., G.G.; Materials - S.Y., M.A., G.G.; Data Collection and/or Processing - S.Y;; Analysis and/or Interpretation - S.Y., G.G.; Literature Search S.Y., G.G.; Writing Manuscript - S.Y.; Critical Review - S.Y., G.G., M.A.

Conflict of Interest: No conflict of interest was declared by the authors.

Financial Disclosure: The authors declared that this study has received no financial support.

\section{REFERENCES}

1. Maclntyre NR, Cook DJ, Ely EW, Epstein SK, Fink JB, Heffner JE, et al. Evidence based guidelines for weaning and discontinuing ventilatory support. Chest 2001; 120: 375S-95S. [CrossRef]

2. Meade M, Guyatt G, Cook D, Griffith L, Sinuff T, Kergl C, et al. Predicting success in weaning from mechanical ventilation. Chest 2001; 120: 40024. [CrossRef]

3. Yang $\mathrm{KL}$, Tobin MJ. A prospective study of indexes predicting the outcome of trials of weaning from mechanical ventilation. $\mathrm{N}$ Eng J Med 1991; 21: 1445-51. [CrossRef]

4. Johanigman JA, Davis K Jr, Campbell RS, Branson RD, Luchette FA, Hurst $J M$. Use of the rapid/shallow breathing index as an indicator of patient work of breathing during pressure support ventilation. Surgery 1997: 737-40. [CrossRef]

5. Ely EW, Baker AM, Evans GW, Haponik EF. The prognostic significance of passing a daily screening of weaning parameters. Intensive Care Med 1999; 25: 581-7. [CrossRef]

6. Ely EW, Bennett PA, Bowton DL, Murphy SM, Florance AM, Haponik EF. Large scale implementation of a respiratory therapist driven protocol for ventilator weaning. Am J Respir Crit Care Med 1999; 159: 439-46. [CrossRef]

7. Esteban A, Alia I, Gordo F, Fernandez R, Solsona JF, Valverdu I, et al. Extubation outcome after spontanous breathing trials with $\mathrm{t}$-tube or pressure support ventilation: The Splanish Lung Failure Colloborative Group. Am J Respir Crit Care Med 1997; 156: 459-65. [CrossRef]
8. Boles JM, Bion J, Connors A, Herridge M, Marsh B, Melot C, et al. Weaning from mechanical ventilation. Eur Respir J 2007; 29: 1033-56. [CrossRef]

9. Chao DC, Scheinhorn DJ. Determining the best thereshold of rapid breathing index in a therapist-implemented patient-specific weaning protocol. Respir Care 2007; 52: 159-65.

10. Kuo PH, Wu HD, Lu BY, Chen MT, Kuo SH, Yang PC. Predictive value of rapid shallow breathing index measured at initiation and termination of a 2-hour spontaneous breathing trial for weaning outcome in ICU patients. J Formos Med Assoc 2006; 105: 390-8. [CrossRef]

11. Esteban A, Alia I, Ibanez J, Benito S, Tobin MJ. Modes of mechanical ventilation and weaning: a national survey of Spanish hospitals; The Spanish Lung Failure Collabarative Group. Chest 1994; 106: 1188-93. [CrossRef]

12. Gursel G, Demirtas S. Value of APACHE II, SOFA and CPIS scores in predicting prognosis in patients with ventilator-associated pneumonia. Respiration 2006; 73: 503-8. [CrossRef]

13. Gursel G. Determinants of the length of mechanical ventilation in patients with COPD in the intensive care unit. Respiration 2005; 72: 61-7. [CrossRef]

14. Tobin MJ. Mechanical ventilation. N Eng J Med 1994; 330: 1056-61. [CrossRef]

15. Gürsel G. Mekanik ventilasyon sırasında solunum monitorizasyonu: II. Tuberk Toraks Derg 2003; 51: 100-6.

16. Hart N, Polkey MI. Investigation of respiratory muscle function. Clin Pulm Med 2001; 8: 180-7. [CrossRef]

17. Chatila W, Jacob B, Guaglionone D, Manthous CA. The unassisted respiratory rate-tidal volume ratio accurately predicts weaning outcome. Am J Med 1996; 101: 61-6. [CrossRef]

18. Lee KH, Hui KP, Chan TB, Tan WC, Lim TK. Rapid shallow breathing (frequency-tidal volume ratio) did not predict extubation outcome. Chest 1994; 105: 540-3. [CrossRef]

19. Bien MY, Shui Lin Y, Shih CH, Yang YL, Lin HW, Bai KJ, et al. Comparisons of predictive performance of breathing pattern variability measured during T-piece, automatic tube compensation, and pressure support ventilation for weaning intensive care unit patients from mechanical ventilation. Crit Care Med 2011; 39: 2253-62. [CrossRef]

20. Perrigault P, Pouzeratte Y, Jaber S, Capdevila XJ, Hayot M, Boccara G, et al. Changes in occlusion pressure (P0.1) and breathing pattern during pressure support ventilation. Thorax 1999; 54: 119-23. [CrossRef]

21. El-Khatib MF, Zeineldine SM, Jamaleddine GW. Effect of pressure support ventilation and positive end expiratory pressure on the rapid shallow breathing index in intensive care unit patients. Intensive Care Med 2008; 34: 505-10. [CrossRef]

22. Gonçalves EC, Silva EC, Filho AB, Auxiliadora-Martins M, Nicolini EA, Gastaldi AC. Low pressure support changes the rapid shallow breathing index (RSBI) in critically ill patients on mechanical ventilation. Rev Bras Fisioter 2012; 16: 368-74. [CrossRef]

23. Patel KN, Ganatra KD, Bates JH, Young MP. Variation in the rapid shallow breathing index associated with common measurement techniques and conditions. Respir Care 2009; 54: 1462-6.

24. Desai NR, Myers L, Simeone F. Comparison of 3 different methods used to measure the rapid shallow breathing index. J Crit Care 2012; 27: 418 e1-6.

25. Zhang B, Qin YZ. Comparison of pressure support ventilation and T- piece in determining rapid shallow breathing index in spontaneous breathing trials. Am J Med Sci 2014; 348: 300-5. [CrossRef]

26. Sassoon CSH, Mahutte CK. Airway occlusion pressure and breathing pattern as predictors of weaning outcome. Am Rev Respir Dis 1993; 148: 860-6. [CrossRef]

27. Brochard L, Rua F, Lorino H, Lemaire F, Harf A. Inspiratory pressure compensates for the additional work of breathing caused by the endotracheal tube. Anesthesiology 1991; 75: 739-45. [CrossRef]

28. Tokioka H, Saito S, Kosaka F. Effect of pressure support ventilation on breathing patterns and respiratory work. Intensive Care Med 1989; 15 491-4. [CrossRef]

29. Berger KI, Sorkin B, Norman RG, Rapoport DM, Goldring RM. Mechanism of relief of tachypnea during pressure support ventilation. Chest 1996; 109: 1320-7. [CrossRef]

30. Ershowsky P, Krieger B. Changes in breathing pattern during pressure support ventilation. Respir Care 1987; 32: 1011-6. 